\title{
PERLINDUNGAN HUKUM BAGI PEMBELI YANG BERITIKAD BAIK TERHADAP AKTA JUAL BELI HAK ATAS TANAH YANG TIDAK SESUAI DENGAN TATA CARA PEMBUATANNYA
}

\author{
I Nyoman Suryana \\ Fakultas Hukum Universitas Teknologi Indonesia Jl. Badak Agung XII Nomor 6 \\ Denpasar \\ (mang85surya@gmail.com)
}

\begin{abstract}
The growing of importance meaning of the land to human life today may causes increase of the potential for conflicts or land disputes, to prevent or at least to reduce the potential for conflict or dispute are required legal and orderly system of land administration. Therefore isrequired to transfer land rights to be registered must be proven by deed of PPAT. As authentic documents PPAT deed must meet procedures for making the deed of PPAT as determined by the laws and other rules. Making the deed that is incompatible with how making PPAT deed may pose a risk to the certainty of land rights arising or recorded on the basis of such deed. Based on this background the authors give the title of this thesis, The Legal Consequences of Making the Deed of Sale and Purchase of Land That is Incompatible With PPAT Deed Making Procedures. The aim of this study is to determine the forms, causes and legal consequences of making the deed of sale and purchase of land not in accordance with the procedure making the deed of PPAT. Precriptive specification research in juridical normative law method is used. The data source that is used are primary and secondary data. The data is collected by analyzing law expert theories and also library research that are related.The method of juridical approach used is empirical research with prescriptive specifications and data sources used are primary andsecondary data. Collecting data is done by doing library research and field study and then after the data were analyzed conclusion is by using the method of inductive thinking.Based on this research found that, the legal effect of making the deed of sale and purchase of land not in accordance with procedures for making the deed of PPAT is: PPAT can be dishonorably discharged, PPAT deed degraded the strength of proof becomes deed under hand and third parties may utilize it to its interests.
\end{abstract}

Keywords: PPAT deed, legal effect, the procedures for making

ABSTRAK, Semakin pentingnya arti tanah bagi kehidupan manusia sekarangini menyebabkan makin meningkatnya potensi untuk timbulnya konflik-konflikatau sengketa pertanahan, untuk mencegah atau paling tidakmengurangi potensi konflik atau sengketa tersebut dibutuhkan perangkathukum dan sistem administrasi pertanahan yang teratur dan tertata rapi.Karenanya diharuskan pemindahan hak atas tanah agar bisa didaftarharus dibuktikan dengan akta PPAT. Sebagai akta otentik akta PPATharuslah memenuhi tata cara pembuatan akta PPAT sebagaimana yangditentukan oleh undang-undang dan peraturan-peraturan lainnya.Pembuatan akta yang tidak sesuai dengan tata cara pembuatan aktaPPAT dapat menimbulkan risiko bagi kepastian hak atas tanah yangtimbul atau tercatat atas dasar akta tersebut. Berdasarkan latar belakangtersebut maka tesis ini penulis beri judul Perlindungan Hukum Terhadap Pembeli Yang Beritikad Baik Atas Akta Jual Beli PPAT Yang TidakSesuai Dengan Tata Cara Pembuatannya.Tujuan penelitian adalah untuk mengetahui lebih dalam mengenai bagaimanakah perlindungan hukum terhadap pembeli yang beritikad baik atas akta jual beli yang tidak sesuai dengan tata cara pembuatan akta PPAT dan untuk mengetahui lebih dalam bagaimanakah akibat hukum dari akta jual beli yang tidak sesuai dengan tata cara pembuatan akta PPAT.Dipakai metode pendekatan kualitatif yaitu metode penelitian yang berlandaskan pada filsafat positivisme dan sumber data yang digunakan adalah data primerdan data sekunder. 
Pengumpulan datanya dilakukan dengan melakukanpenelitian kepustakaan kemudian setelah bahan hukum selesai dianalisis maka akan disajikan dengan teknik deskripsi sistematis.Berdasarkan hasil penelitian ditemukan bahwa akibat hukum daripembuatan akta jual beli tanah yang tidak sesuai dengan tata cara pembuatan akta PPAT adalah: PPAT dapat diberhentikan dengan tidakhormat, akta PPAT terdegradasi kekuatan pembuktiannya menjadi akta dibawah tangan dan pihak ketiga dapat memanfaatkan hal ini untukkepentingannya.

\section{Kata Kunci: Perlindungan Hukum, Akta Jual Beli PPAT}

\section{PENDAHULUAN}

Pada awalnya tanah hanya sebagai tempat untuk tinggal atau pemukiman dan sebagai lahan untuk pertanian. Namun pada perkembangannya karena semakin meningkatnya kebutuhan hidup pertambahan jumlah penduduk serta perkembangan teknologi dan pertumbuhan ekonomi, tanah akhirnya juga difungsikan sebagai tempat untuk kegiatan industri kegiatan untuk usaha lain dan bangunanbangunan komersial dan lain sebagainya.

Tanah mempunyai arti penting dalam kehidupan manusia karena tanah mempunyai fungsi ganda yaitu sebagai social asset dan sebagai capital asset.Sebagai sosial asset tanah merupakan sarana pengikat kesatuan sosial di kalangan masyarakat Indonesia.Sedangkan sebagai capital asset tanah telah tumbuh sebagai benda ekonomi yang sangat penting tidak saja sebagai bahan perniagaan tetapi juga sebagai obyek spekulasi. Di satu sisi tanah harus dipergunakan dan dimanfaatkan sebesar-besarnya untuk kesejahteraan dan kemakmuran rakyat sedangkan disisi lain harus di jaga kelestariannya. ${ }^{1}$

Maka masalah jual beli tidak dapat dipisahkan dari kehidupan masyarakat sehari-hari dan etikad jual beli merupakan faktor yang penting sehingga pembeli yang beritikad baik akan dapat perlindungan hukum secara wajar menurut peraturan perundang-undangan yang berlaku. Sedangkan yang tidak beritikad baik maka tidak perlu untuk mendapatkan perlindungan hukum.Itikad baik sebernarnya tidak hanya mengacu kepada itikad baik para pihak, tetapi harus pula mengacu kepada nilai-nilai yang

${ }^{1}$ Achmad Rubaie, 2007, Hukum Pengadaan Tanah Untuk Kepentingan Umum, Bayumedia, Malang,hal. 1 
berkembang dalam masyarakat, sebab

itikad baik merupakan bagian dari

masyarakat. Itikad baik ini akhirnya

mencerminkan standar keadilan atau

kepatutan masyarakat ${ }^{2}$

Tanah sebagai satu bagian dari unsur negara, menjadi bagian yang sangat penting bagi kesejahteraan bangsa. Dalam kaitan itu, Negara mempunyai tugas dan wewenang untuk menggariskan nilai-nilai dalam upaya menata struktur pertanahan yang berkeadilan dan berwawasan kesejahteraan, sebagai berikut: ${ }^{3}$

a. Semua hak atas tanah mempunyai fungsi sosial.

b. Pemilikan dan penguasaan tanah yang melampaui batas tidakdiperkenankan.

c. Tanah harus dikerjakan sendiri secara aktif oleh pemiliknya dan mencegah cara-cara pemerasan.

d. Usaha dalam bidang agraria tidak boleh bersifat monopoli.

${ }^{2} \mathrm{P}$. van Warmelo, 1976, An Introduction to the Principles of Roman Law, Juta and Co.Ltd, Cape Town, hal. 151.

3JW.Muliawan, 2009, Pemberian Hak Milik Untuk Rumah Tinggal, Cerdas Pustaka Publisher, Jakarta,hal.84 e. Menjamin kepentingan golongan ekonomi lemah, dan

f. Untuk kepentingan bersama.

Untuk dapat memberikan perlindungan terhadap pemilik tanah serta dapat mengatur kepemilikan, peralihan dan peruntukan tanah secara adil dan menyeluruh serta untuk dapat mewujudkan cita-cita luhur bangsa Indonesia, sebagaimana tertuang dalam pembukaan Undang-Undang Dasar 1945 dan untuk dapat mengejawantahkan amanat Pasal 33 Ayat (3) Undang-Undang Dasar 1945 yang menyatakan :

"Bumi, air dan kekayaan alam yang terkandung di dalamnya dikuasai oleh negara dan dipergunakan sebesarbesarnya untuk kemakmuran rakyat",perlulah diciptakan suatu Hukum Agraria Nasional atau UndangUndangPokok Agraria (UUPA).

Pada tanggal 24 September 1960 disahkan oleh Presiden RepublikIndonesia Soekarno dan diundangkan dalam Lembaran Negara RepublikIndonesia Nomor 104 Tahun 1960, Undang-Undang Nomor 5 Tahun 1960 tentang Peraturan Dasar Pokok Pokok Agraria yang lebih dikenal dengannama resminya UndangUndang Pokok Agraria disingkat UUPA. 
Dengan diundangkannya UUPA

pada tanggal tersebut, sejak itu tanggal 24

September 1960 tercatat sebagai salah satu tanggal danmerupakan salah satu tonggak yang sangat penting dalam sejarahperkembangan agraria/pertanahan di Indonesia pada umumnya danpembaruan Hukum Agraria/Hukum Tanah Indonesia pada khususnya. ${ }^{4}$

Dengan diundangkannya UndangUndang Nomor 5 Tahun 1960atau UUPA ini, maka pada hakekatnya undang-undang ini telahmengakhiri berlakunya peraturanperaturan Hukum Tanah Kolonial danjuga mengakhiri adanya dualisme dan pluralisme Hukum Tanah diIndonesia.

UUPA menciptakan Hukum Agraria Nasional berstruktur tunggalyang seperti dinyatakan dalam bagian "berpendapat" serta Penjelasanumum UUPA, bahwa UUPA berdasarkan atas Hukum Adat tentang tanah,sebagai hukum aslinya bagian terbesar rakyat Indonesia. ${ }^{5}$

${ }^{4}$ Boedi Harsono, 2007, Hukum Agraria Indonesia, Sejarah Pembentukan Undang-Undang Pokok Agraria, Isi dan Pelaksanaanya, Djambatan,Jakarta, hal. 3 ${ }^{5}$ Ibid, hal. 1
UUPA sebagai peraturan dasar yang mengatur pokok-pokok keagrariaan dan merupakan landasan hukum tanah nasional, tidak memberikan pengertian yang tegas, baik mengenai istilah "tanah" maupun istilah "agraria". Dari ketentuanketentuan Pasal 1 Ayat (4), (5), dan (6) jo Pasal 2 Ayat (1) UUPA dapat ditarik kesimpulan bahwa pengertian agraria mengandung makna yang luas, yang meliputi bumi, air, ruang angkasa dan kekayaan alam yang terkandung di dalamnya ${ }^{6}$

Dengan adanya Undang-Undang Pokok Agraria ini, atas dasar ketentuan dalam Pasal 33 Ayat (3) Undang-Undang Dasar 1945 terutama kata-kata "dikuasai oleh negara", seperti disebut oleh Pasal 2 Ayat (2) UUPA, maka negara sebagai organisasi kekuasaan seluruh rakyat pada tingkatan tertinggi menguasai seluruh tanah. Dalam arti, negara mempunyai wewenang untuk:

a. Mengatur dan menyelenggarakan peruntukan, penggunaan, persediaan dan

${ }^{6}$ Ida Nurlinda, 2009, Prinsip-Prinsip Pembaruan Agraria Perspektif Hukum, Rajawali Pers, Jakarta,hal. 37 
pemeliharaan bumi, air dan ruang angkasa tersebut.

b. Menentukan dan mengatur hubunganhubungan hukum antara orang-orang dengan bumi, air dan ruang angkasa.

c. Menentukan dan mengatur hubunganhubungan hukum antara orang-orang dan perbuatan-perbuatan hukum yang mengenai bumi, air dan ruang angkasa.

$$
\text { Untuk melaksanakan }
$$

kewenangannya tersebut, UUPA khususnya

Pasal 19, yang menyatakan:

1. Untuk menjamin kepastian hukum oleh Pemerintah diadakan pendaftaran tanah diseluruh wilayah Republik Indonesia menurutketentuan-ketentuan yang diatur dengan Peraturan Pemerintah.

2. Pendaftaran tersebut dalam Ayat (1) pasal ini meliputi:
a. pengukuran perpetaan dan pembukuan tanah
b. Pendaftaran hak-hak atas tanah dan peralihan hak-hak tersebut;
c. Pemberian surat-surat tanda bukti hak, yang berlaku sebagai alat pembuktian yang kuat.

3. Pendaftaran tanah diselenggarakan dengan mengingat keadaan Negara dan masyarakat, keperluan lalu-lintas sosial ekonomi serta kemungkinan penyelenggaraannya, menurut pertimbangan Menteri Agraria.

4. Dalam Peraturan Pemerintah diatur biaya-biaya yang bersangkutan dengan pendaftaran termaksud dalam ayat (1) diatas, dengan ketentuan bahwa rakyat yang tidak mampu dibebaskan dari pembayaran biaya-biaya tersebut"mewajibkan kepada negara untuk melaksanakan pendaftaran tanah, yang diselenggarakan dalam rangka menjamin kepastian hukum di bidang pertanahan (suatu Rechtkadaster atau Legal cadastre.$^{7}$

Untuk melaksanakan amanat Pasal 19 ayat (4) UUPA tentang Pendaftaran Tanah tersebut pemerintah mengeluarkan Peraturan Pemerintah Nomor 10 Tahun 1961 tentang Pendaftaran Tanah dan sekarang diganti dengan Peraturan Pemerintah Nomor 24 Tahun 1997, dimana kaitan antara Peraturan Pemerintah Nomor 10 Tahun 1961 dengan Peraturan Pemerintah Nomor 24 Tahun 1997 bahwa secara substansi adalah sama yaitu mengatur tentang pendaftaran tanah. Namun Peraturan Pemerintah Nomor 24 Tahun 1997 itu sendiri merupakan PP pengganti dari PP Nomor 10 Tahun 1961, dalam hal ini PP Nomor 10 Tahun1961 dianggap tidak dapat lagi sepenuhnya mendukung tercapainya hasil yang lebih nyata pada pembangunan nasional sehingga perlu dilakukan penyempurnaan maka disusunlah Peraturan Pemerintah 24 Tahun 1997. Hal ini dijelaskan dalam "Penjelasan Umum" Peraturan Pemerintah Nomor 24

${ }^{7}$ Boedi Harsono Op.Cit, hal. 472 
Tahun 1997 tentang Pendaftaran Tanah

yang menyatakan :

"Dalam kenyataannya pendaftaran tanah yang diselenggarakan berdasarkan Peraturan Pemerintah Nomor 10 Tahun 1961 tersebut selama lebih dari 35 tahun belum cukup memberikan hasil yang memuaskan.Sehubungan dengan itu maka dalam rangka meningkatkan dukungan yang lebih baik pada pembangunan nasional dengan memberikan kepastian hukum di bidang pertanahan, dipandang perlu untuk mengadakan penyempurnaan pada ketentuan yang mengatur pendaftaran tanah"

Pada Peraturan Pemerintah Nomor

24 Tahun 1997 tentang Pendaftaran Tanah

ini yang dimaksud dengan pendaftaran

tanah, sebagaimana disebut oleh Pasal 1

ayat (1), menyatakan :

Pendaftaran tanah adalah rangkaian kegiatan yang dilakukan oleh Pemerintah secara terus menerus, berkesinambungan dan teratur, meliputi pengumpulan, pengolahan, pembukuan, dan penyajian serta pemeliharaan bahan hukum fisik dan bahan hukum yuridis, dalam bentuk peta dan daftar, mengenai bidang-bidang tanah dan satuansatuan rumah susun, termasuk pemberian surat tanda bukti haknya bagi bidang-bidang tanah yang sudah ada haknya dan hak milik atas satuan rumah susun serta hakhak tertentu yang membebaninya.

Dalam Peraturan Pemerintah

Nomor 24 Tahun 1997 tentang Pendaftaran

Tanah yang menyempurnakan Peraturan
Pemerintah Nomor 10 Tahun 1961 tentang

Pendaftaran Tanah ini, tetap dipertahankan

tujuan diselenggarakannya pendaftaran

tanah sebagai yang pada hakikatnya sudah

ditetapkan oleh Pasal 19 UUPA, yaitu

bahwa pendaftaran tanah merupakan tugas

pemerintah yang diselenggarakan dalam

rangka menjamin kepastian hukum di

bidang pertanahan.

Tujuan pendaftaran tanah menurut

Peraturan Pemerintah Nomor 24 Tahun

1997 tentang Pendaftaran Tanah,

sebagaimana termuat dalam Pasal 3

menyatakan :

Pendaftaran tanah bertujuan:

a. Untuk memberikan kepastian hukum dan perlindungan kepada pemegang hak atas suatu bidang tanah, satuan rumah susun dan hakhak lain yang terdaftaragar dengan mudah dapat membuktikan dirinya sebagai pemegang hak yang bersangkutan.

b. Untuk menyediakan informasi kepada pihak-pihak yang berkepentingan termasuk pemerintah agar dengan mudah dapat memperoleh bahan hukum yang diperlukan dalam mengadakan perbuatan hukum mengenai bidangbidang tanah dan satuan-satuan rumah susun yang sudah terdaftar.

c. Untuk terselenggaranya tertib administrasi pertanahan.

Pendaftaran Hak dan Pendaftaran

Peralihan Hak Atas Tanah ini sebagaimana 
diatur dalam Pasal 19 Ayat (2) sub b

UUPA, merupakan sebagian dari tugas dan wewenang pemerintah di bidang pendaftaran tanah. Di bidang ini, pendaftaran hak dan pendaftaran peralihan hak dapat dibedakan 2 tugas, yaitu :

1. Pendaftaran Hak atas Tanah, adalah pendaftaran hak untuk pertama kalinya atau pembukuan suatu hak atas tanah dalam daftar buku tanah.

2. Pendaftaran Peralihan Hak atas Tanah. ${ }^{8}$

Pendaftaran Peralihan Hak Atas Tanah merupakan perbuatan hukum pemindahan hak atas tanah yang dilakukan dengan sengaja supaya hak tersebut terlepas dari pemegangnya semula dan menjadi hak pihak lain. Menurut pasal 37 ayat (1) Peraturan Pemerintah Nomor 24 Tahun 1997 ditegaskan bahwa :

Peralihan hak atas tanah dan hak milik atas satuan rumah susun melalui jual beli, tukar menukar, hibah, pemasukan dalam perusahaan dan perbuatan hukum pemindahan hak lainnya, kecuali pemindahan hak melalui lelang

${ }^{8}$ Ali Achmad Chomsah, 2004, Hukum Agraria (Pertanahan Indonesia) Jilid 2 Prestasi Pustaka Publisher, Jakarta, hal. 37 hanya dapat didaftarkan jika dibuktikan dengan akta yang dibuat oleh PPAT yang berwenang menurut ketentuan Peraturan Perundang-undangan yang berlaku. Berdasarkan Peraturan Pemerintah

Nomor 24 Tahun 2016 tentang Perubahan Atas Peraturan Pemerintah Nomor 37 Tahun 1998 tentang Peraturan Jabatan Pejabat Pembuat Akta Tanah. Dalam Peraturan Pemerintah Nomor 24 Tahun 2016 pada pasal 1 ayat (1)menyatakan :

Pejabat Pembuat Akta Tanah, selanjutnya disebut dengan PPAT adalah pejabat umum yang diberi kewenangan untuk membuat aktaakta otentik mengenai perbuatan hukum tertentu mengenai hak atas tanah atau hak milik atas satuan rumah susun.

Demikian pentingnya akta yang dibuat oleh PPAT dalam rangka peralihan hak atas tanah, maka pendaftaran peralihan hak atas tanah, kecuali pendaftaran peralihan hak melalui lelang hanya dapat dilakukan apabila dibuktikan dengan akta yang dibuat oleh PPAT.

Akta PPAT adalah akta otentik dan sebagai sebuah akta otentik terdapat persyaratan ketat dalam hal prosedur pembuatan, bentuk dan formalitas yang harus dilakukan sehingga akta tersebut 
berhak disebut sebagai akta otentik. Hal ini ditegaskan oleh Pasal 1868 KUHPerdata :

"Suatu akta otentik ialah suatu akta yang dibuat dalam bentuk yang ditentukan undang-undang oleh atau dihadapan pejabat umum yang berwenang untuk itu di tempat akta itu dibuat"

Jadi unsur-unsur suatu akta otentik yaitu :

1. Dalam bentuk yang ditentukan oleh undang-undang

2. Oleh atau dihadapan Pejabat Umum

3. Pejabat tersebut harus berwenang di tempat di mana akta tersebut dibuat.

Mengenai jenis dan bentuk akta, pelaksanaan dan prosedurpembuatannya, diatur oleh Peraturan Menteri Negara Agraria KepalaBadan Pertanahan Nasional Nomor 3 Tahun 1997 mengenai KetentuanPelaksanaan Peraturan Pemerintah Nomor 24 Tahun 1997 tentang Pendaftaran Tanah

Akta PPAT merupakan salah satu sumber bahan hukum bagi pemeliharaandata pendaftaran tanah, maka wajib dibuat sedemikian rupa sehinggadapat dijadikan dasar yang kuat untuk pendaftaran pemindahan danpembebanan hak atas tanah.Oleh karena itu PPAT bertanggungjawab untuk memeriksa syarat-syarat untuk sahnya perbuatan hukumyang bersangkutan. Antara lain mencocokkan data yang terdapat dalamsertifikat dengan daftardaftar yang ada di Kantor Pertanahan. ${ }^{9}$

Tata cara dan formalitas pembuatan akta otentik adalah merupakan ketentuan hukum yang memaksa, artinya tata cara dan prosedur pembuatan itu harus diikuti dengan setepat-tepatnya tanpa boleh disimpangi sedikitpun. Penyimpangan dari tatacara dan prosedur pembuatan akta otentik akan membawa akibat hukum kepada kekuatan pembuktian akta itu.

Meskipun prosedur untuk melaksanakan peralihan (Peralihan hak atas tanah bisa terjadi karena pewarisan tanpa wasiat dan perbuatan hukum pemindahan hak) ${ }^{10}$ atau pemindahan hak atas tanah (hak atas tanah yang bersangkutan sengaja dialihkan kepada pihak lain), ${ }^{11}$ misalnya dalam jual beli tanah sangat ketat, tapi 
dalam setiap peralihan atau pemindahan hak atas tanah selalu terbuka kemungkinan adanya tuntutan dari pihak ketiga, bahwa tanah tersebut adalah miliknya. Jadi meskipun peralihan hak atas tanah tersebut sudah dilaksanakan melalui akta PPAT, tetap terbuka kemungkinan akan dapat menimbulkan sengketa pertanahan.Hal ini baik yang disebabkan oleh adanya pihak ketiga yang merasa mempunyai hak atau yang disebabkan oleh adanya kesalahan pada PPAT yang membuat aktanya atau adanya cacat hukum pada aktanya baik yang disebabkan oleh karena adanya penyimpangan atau kesalahan pada pembuatan aktanya.

\section{AKIBAT HUKUM DARI AKTA}

JUAL BELI YANG TIDAK SESUAI DENGAN TATA CARA PEMBUATAN AKTANYA

Jual beli merupakan suatu proses peralihan hak atas tanah maupun benda lainnya. Semenjak diterbitkannya UndangUndang Nomor 5 Tahun 1960 tentang Peraturan Dasar Pokok-Pokok Agraria maka diterbitkan suatu Peraturan
Pemerintah Nomor 24 Tahun 2016 tentang

Perubahan Atas Peraturan Pemerintah

Nomor 37 Tahun 1998 tentang Jabatan

Pejabat Pembuat Akta Tanah dalam Pasal 1

di sebutkan bahwa;

1. Pejabat pembuat akta tanah, selanjutnya disebut PPAT adalah pejabat umum yang diberi kewenangan untuk membuat akta-akta otentik mengenai perubahan hukum tertentu mengenai hak atas tanah atau hak milik atas satuan rumah susun.

2. PPAT sementara adalah pejabat pemerintah yang ditunjuk karena jabatannya untuk melaksanakan tugas PPAT dengan membuat akta PPAT di daerah yang belum cukup terdapat PPAT.

3. PPAT khusus adalah pejabat badan pertanahan nasional yang ditunjuk karena jabatannya untuk melaksanakan tugas PPAT dengan membuat akta PPAT tertentu khusus dalam rangka pelaksanaan program atau tugas pemerintahan tertentu.

4. Akta PPAT adalah akta yang dibuat PPAT sebagai bukti telah dilaksanakannya perbuatan hukum tertentu mengenai hak atas tanah atau hak milik atas satuan rumah susun.

5. Protokol PPAT adalah kumpulan dokumen yang harus disimpan dan dipelihara oeh PPAT yang terdiri dan daftar akta, akta asli, warkah pendukung akta, arsip laporan, agenda dan surat-surat lainnya.

6. Warkah adalah dokumen yang dijadikan dasar pembuatan akta PPAT.

7. Dihapus

8. Daerah kerja PPAT adalah suatu wilayah yang menunjukan kewenangan seorang PPAT untuk membuat akta mengenai hak atas tanah dan hak milik atas satuan rumah susun yang terletak didalamnya.

9. Menteri adalah mentri yang menyelenggarakan urusan 
pemerintahan

di

agraria/pertanahan.

PPAT melaksanakan sebagian dari kegiatan pendaftaran tanah dengan tugas pembuatan akta otentik sebagai bukti telah dilakukannya perbuatan hukum tertentu mengenai hak atas tanah atau hak milik atas satuan rumah susun. Maka akta jual beli yang dibuat dan ditandatangani dihadapan pejabat pembuat akta tanah (PPAT) membuktikan bahwa benar telah dilakukan perbuatan hukum pemindahan hak atas tanah dan disertai dengan pembayaran harga, serta membuktikan bahwa penerima hak atau pembeli sudah menjadi pemegang hak yang baru dengan memiliki bukti dari kepemilikan atas tanah tersebut. Berdasarkan Peraturan Menteri

Agraria/Kepala Badan Pertanahan Nasional

Nomor 3 Tahun 1997 tentang Ketentuan

Pelaksanaan Peraturan Pemerintah Nomor

24 Tahun 1997 tentang Pendaftaran Tanah,

bahwa syarat formal dalam pembuatan akta jual beli oleh PPAT yang diatur dalam

Pasal 97 sebagai berikut;

1. Sebelum melaksanakan pembuatan akta mengenai pemindahan atau pembebanan hak atas tanah atau hak milik atas satuan rumah susun PPAT wajib terlebih dahulu melakukan pemeriksaan pada kantor pertanahan mengenai kesesuaian sertifikat hak atas tanah atau hak milik atas satuan rumah susun yang bersangkutan dengan daftar-daftar yang ada di Kantor Pertanahan setempat dengan memperlihatkan sertifikat asli.

2. Pemeriksaan sertifikat sebagaimana yang dimaksud pada ayat (1) dilakukan untuk setiap pembuatan akta oleh PPAT, dengan ketentuan bahwa untuk pembuatan akta pemindahan atau pembebanan hak atas bagian-bagian tanah hak induk dalam rangka pemasaran hasil pengembangan oleh perusahaan real astat, kawasan industri dan pengembangan sejenis cukup dilakukan pemeriksaan sertifikat tanah induk satu kali, kecuali apabila PPAT yang bersangkutan menganggap perlu pemeriksaan sertifikat ulang.

3. Apabila sertifikat sebagaimana yang dimaksud pada ayat (1) sesuai dengan daftar-daftar yang ada di kantor pertanahan, maka kepala kantor pertanahan atau pejabat yang di tunjuk membubuhkan cap atau tulisan dengan kalimat:

"telah diperiksa dan sesuai dengan daftar di kantor Pertanahan"

Pada halaman perubahan sertifikat asli kemudian di paraf dan diberi tanggal pengecekan.

4. Pada halaman buku tanah yang bersangkutan dibubuhkan cap atau tulisan dengan kalimat:

"PPAT......(nama PPAT ybs).......telah minta pengecekan sertifikat"

Kemudian diparaf dan diberi tanggal pengecekan.

5. Apabila sertifikat sebagaimana dimadsud dalam ayat (1) ternyata tidak sesuai dengan daftar-daftar yang ada di Kantor Pertanahan, maka diambil tindakan sebagai berikut :

a. Apabila sertifikat tersebut bukan dokumen yang diterbitkan oleh Kantor Pertanahan, maka pada sampul dan semua halaman sertifikat tersebut dibubuhkan cap atau dengan tulisan dengan kalimat: "sertifikat ini tidak diterbitkanoleh Kantor Pertanahan. ," Kemudian di paraf. 
b. Apabila sertifikat tersebut adalah dokumen yang diterbitkan oleh Kantor Pertanahan akan tetapi data fisik dan atau data yuridis yang termuat didalamnya tidak sesuai lagi dengan data yang tercatat dalam buku tanah dan atau surat ukur yang bersangkutan, kepada PPAT yang bersangkutan diterbitkan surat keterangan pendaftaran tanah sesuai data yang tercatat di Kantor Pertanahan dan pada sertifikat yang bersangkutan tidak dicantumkan sesuatu tanda.

6. Sertifikat yang sudah diperiksa kesesuaian dengan daftar-daftar di Kantor Pertanahan tersebut dikembalikan kepada PPAT yang bersangkutan.

7. Pengembalian sertifikat sebagaimana dimadsud pada ayat (6) dilakukan pada hari yang sama dengan hari pengecekan

8. Penerbitan SKPT sebagaimana dimaksud pada ayat (5) huruf b dilakukan selambat-lambatnya dalam 7 hari kerja terhitung dari hari pengecekan.

Di dalam pembuatan akta jual beli oleh PPAT sesuai dengan Peraturan Menteri Negara Agraria/Kepala Badan Pertanahan Nasional Nomor 3 Tahun 1997 dalam Pasal 101 menyebutkan:

1. Pembuatan akta PPAT harus dihadiri oleh para pihak yang melakukan perbuatan hukum yang bersangkutan atau orang yang dikuasakan olehnya dengan surat kuasa tertulis sesuai dengan peraturan perundang-undangan yang berlaku.

2. Pembuatan akta PPAT harus disaksikan oleh sekurangkurangnya 2 orang saksi yang menurut ketentuan peraturan perundang-undangan yang berlaku memenuhi syarat untuk bertindak sebagai saksi dalam suatu perbuatan hukum. Yang memberi kesaksian antara lain mengenai kehadiran para pihak atau kuasanya, keberadaan dokumendokumen yang ditunjukan dalam pembuatan akta, dan telah dilaksanakannya perbuatan hukum tersebut oleh para pihak yang bersangkutan.

3. PPAT wajib membacakan akta kepada para pihak yang bersangkutan dan memberikan penjelasan mengenai isi dan madsud pembuatan akta, dan prosedur pendaftaran yang harus dilaksanakan selanjutnya sesuai dengan ketentuan yang berlaku.

Kewenangan Pejabat Pembuat Akta Tanah (PPAT) dalam perjanjian jual beli atas tanah yaitu PPAT melaksanakan sebgian dari kegiatan pendaftaran tanah dengan tugas pembuatan akta (otentik) sebagai bukti telah dilakukan perbuatan hukum tertentu mengenai hak atas tanah. Berdasarkan Peraturan Kepala Badan Pertanahan Nasional Republik Indonesia Nomor 8 Tahun 2013 tentang Lembaga Pendidikan Tinggi Penyelenggara Program Pendidikan Khusus Pejabat Pembuat Akta Tanah yang termuat dalam Pasal 1 ayat (1) "Pejabat pembuat akta tanah, selanjutnya di sebut dengan PPAT adalah pejabat umum yang diangkat oleh Kepala Badan Pertanahan Nasional Republik Indonesia dengan kewenangan membuat akta otentik 
sebagai bukti telah dilakukannya perbuatan hukum tertentu mengenai hak atas tanah atau hak milik atas satuan rumah susun".

Berdasarkan uraian diatas maka dapat di pahami bahwa perjanjian jual beli tanah merupakan suatu perjanjian dimana para pihak mengikatkan diri untuk melakukan perbuatan hukum jual beli dimana tanah menjadi obyeknya, perjanjian jual beli tanah harus memenuhi syarat formal dimana syarat formal akan menentukan sahnya suatu perjanjian jual beli tanah tersebut.

Prakteknya, pembuatan akta jual beli tanah oleh PPAT banyakyang tidak sesuai dengan tata cara pembuatan akta PPAT. Hal inidisebabkan oleh adanya situasi-situasi dan kondisi-kondisi dalam jualbeli yang menyebabkan ketidaksesuaian tersebut sepertinya harusdilakukan agar transaksi atau proses jual beli tanah bisa dilangsungkan. Situasi-situasi dan atau kondisi-kondisi seperti inimembuat PPAT kadang-kadang tidak mempunyai pilihan lain selainmelakukan pembuatan akta jual beli tanah dengan "mengabaikan" tatacara pembuatan akta jual beli tanah sebagaimana diatur olehPeraturan Pemerintah Nomor 24 Tahun 1997 tentang PendaftaranTanah, Peraturan Pemerintah Nomor 24 Tahun 2016 tentang perubahan atas Peraturan Pemerintah Nomor 37 Tahun 1998 tentangPeraturan Jabatan Pejabat Pembuat Akta Tanah serta peraturanperaturanpelaksanaannya.

Selain itu, dalam kenyataan PPAT acapkali menghadapi dilema,di satu pihak mereka harus tunduk kepada ketentuan dengan sifatnyayang normatif, sementara di pihak lain, kenyataan lapangan yangbegitu kompleks sering tidak bisa ditangani dan ditampung olehperaturan yang begitu kaku.Oleh karena itu dalam konteks situasitersebut, PPAT melakukan penafsiran terhadap peraturan yang adauntuk melayani kliennya.Penafsiran dalam konteks situasi antaraPPAT dan klien tidak dapat dihindari, di satu sisi PPAT karenafungsinya harus melayani klien, sedangkan di lain sisi, klienmembutuhkan pelayanan tanpa terlalu peduli dengan peraturan yangmengikat PPAT.Dengan demikian yang terjadi adalah rasionalisasiantara kebutuhan PPAT dan 
kliennya, artinya dalam usaha menjagakelangsungan pekerjaannya, PPAT membutuhkan klien sementaraklien sering tidak mau direpotkan oleh persyaratanpersyaratan teknisyang disyaratkan secara hukum $^{12}$.

Pemecahan dari masalah ini dilakukan dengan cara,pembayaran pajakpajak dilakukan oleh PPAT. Sewaktu para pihakdatang untuk melaksanakan penandatanganan akta jual beli dihadapan PPAT terlebih dulu dibuat rekapitulasi tentang berapajumlah penerimaan bersih yang akan diterima oleh pembeli setelahdikurangi dengan kewajibankewajibannya seperti pembayaranPajak Penghasilan Atas Penghasilan dari Pengalihan Hak AtasTanah dan/atau Bangunan, biaya akta jual beli dan biayabiayalainnya. Kemudian terhadap pembeli dilakukan rekapitulasi jugaterhadap pengeluaran-pengeluaran pembeli, seperti hargatransaksi, biaya akta jual beli, pembayaran Bea Perolehan HakAtas Tanah

12 J. Kartini Soedjendro,2001, Perjanjian Peralihan Hak Atas Tanah yang Berpotensi Konflik,Kanisius, Yogyakarta, hal. 26. dan Bangunan (BPHTB), biaya balik nama dan biaya-biayalainnya. Kemudian kewajiban-kewajiban pembeli danpengeluaran-pengeluaran penjual tersebut oleh pembeli dibayarpanjar lebih dahulu. Pembayaran atas pajak-pajak akan dilakukan olehPPAT, sehingga uang untuk pembayaran pajak-pajak akandisetorkan ke rekening PPAT. Kemudian pembayaran untuk biayaakta jual beli, biaya balik nama dan biaya-biaya lain yangmerupakan hak PPAT juga disetorkan ke rekening PPAT.

Setelah akta jual beli ditandatangani, PPAT mengatakankepada para pihak bahwa akta jual beli tersebut belum akan diberinomor dan belum akan diberi tanggal sampai pembeli melakukanpelunasan harga jual beli kepada penjual. Kemudian penjual danpembeli bersama-sama dengan seorang pegawai PPAT menujubank yang telah disepakati sebelumnya. Pembayaran dilakukandengan cara pembeli melakukan transfer ke rekening penjualsejumlah uang yang merupakan pembayaran atas harga jual belisetelah dikurangi dengan kewajibankewajiban penjual. Setelahtransfer diterima 
oleh penjual maka, pegawai PPAT memintapenjual menandatangani kuitansi yang telah dipersiapkansebelumnya yang menyatakan bahwa pembayaran harga jual belitelah diterima oleh penjual. Setelah itu pembeli juga mentransfersejumlah uang ke rekening PPAT untuk pembayaran pajakpajakpenjual dan pembeli serta biaya-biaya lain yang sudah disepakatisebelumnya.

Untuk dapat disebut sebagai akta otentik suatu akta haruslah memenuhi persyaratan-persyaratan tertentu yang ditetapkan oleh undang-undang atau peraturan-peraturan lainnya.Suatu akta pada dasarnya memiliki ragam fungsi berkenaan dengan tindakan hukum, antara lain, fungsi menentukan keabsahan (Menurut Mochammad Dja'is dan RMJ Koosmargono, akta dilihat dari fungsinya untuk menentukan lengkap atau sempurnanya (bukan sahnya) suatu perbuatan hukum), atau syarat pembentukan dan fungsi sebagai alat bukti ${ }^{13}$.Dilihat dari segi fungsinya sebagai

${ }^{13}$ Herlien Budiono, 2006, Asas Keseimbangan Bagi Hukum Perjanjian Indonesia Hukum Perjanjian Berlandaskan alat bukti, akta otentik mempunyai kekuatan pembuktian sempurna (hanya satu bukti cukup sebagai dasar pemutus perkara, akta otentik dianggap benar adanya dan pihak yang membantah dibebani untuk membuktikan kebenaran bantahannya) ${ }^{14}$.

Menurut Pasal 1869 KUHPerdata, akta otentik dapat turun atau terdegradasi kekuatan pembuktiannya dari mempunyai kekuatan pembuktian sempurna menjadi hanya mempunyai kekuatan pembuktian sebagai tulisan di bawah tangan, jika pejabat umum yang membuat akta itu tidak berwenang untuk membuat akta tersebut atau jika akta tersebut cacat dalam bentuknya. Kata-kata berwenang dalam Pasal 1868 dan Pasal 1869 KUHPerdata mempunyai arti bahwa pembuatan akta tersebut dibatasi oleh tugas wewenang pejabat yang bersangkutan dan wilayah kerjanya. Seorang Pegawai Urusan Agama, dapat membuat akta secara otentik, misalnya akta nikah tetapi keterangannya tentang bebas G.30S/PKI tidak berlaku,

Asas-Asas Wigati Indonesia, PT. Citra Aditya Bakti, Bandung, hal. 256.

${ }^{14}$ Mochammad Dja'is dan RMJ Koosmargono, Op. Cit, hal. 157. 
karena pembuatan surat demikian bukan termasuk kewenangan tugasnya.

Tentang akibat hukum dari akta jual beli tanah yang tidak sesuai dengan tata cara pembuatan akta PPAT, haruslah dibedakan antara akta PPAT itu sendiri dan perjanjian jual beli yang dituangkan ke dalam akta oleh para pihak. Meskipun aktanya terdegradasi kekuatan pembuktiannya tetapi perjanjian jual beli di antara para pihak adalah tetap sah sepanjang syarat-syarat perjanjian jual belinya terpenuhi.

Dalam hal pembuatan akta jual beli tanah dengan konstruksi pembuatan akta jual beli sebagai berikut:

1. Akta jual beli telah ditandatangani tetapi harga pembelian belum dibayar lunas oleh pembeli serta Pajak Penghasilan Atas Penghasilan dari Pengalihan Hak Atas Tanah dan/atau Bangunan yang diatur Peraturan Pemerintah Nomor 34 Tahun 2016 tentang Perubahan Ketiga Atas Peraturan Pemerintah Nomor 48 Tahun 1994 tentang Pembayaran Pajak Penghasilan Atas Penghasilan dari
Pengalihan Hak Atas Tanah dan/atau Bangunan) dan pajak atau Bea Perolehan Hak Atas Tanah dan Bangunan (BPHTB) berdasarkan Undang-Undang Nomor 28 Tahun 2009 tentang BPHTB juga belum dibayar, akibat hukumnya adalah :

a. Akta terdegradasi kekuatan pembuktiannya menjadi akta di bawah tangan karena tidak memenuhi persyaratan yang ditentukan oleh undang-undang dan atau peraturan-peraturan lain.

b. PPAT yang membuat aktanya dikenakan sanksi administratif dan denda yang diatur dalam UndangUndang Nomor 28 Tahun 2009 tentang Perubahan Atas UndangUndang Nomor 21 Tahun 1997 tentang Bea BPHTB juga belum dibayar: Pejabat PembuatAkta Tanah/Notaris dan Pejabat Lelang Negara yang melanggar ketentuan sebagaimana dimaksud dalam Pasal 24 Ayat (1) dan Ayat (2), dikenakan sanksi administrasi dan denda sebesar Rp.7.500.000,00 
(tujuh juta lima ratus ribu rupiah) untuk setiap pelanggaran).

III. PERLINDUNGAN HUKUM BAGI

c. Para pihak atau pihak ketiga yang berkepentingan dapat memanfaatkan keadaan ini, misalkan pihak ketiga tersebut akan mengajukan gugatan akan tetapi terbentur oleh adanya akta otentik yang memiliki kekuatan pembuktian yang sempurna(hanya satu bukti cukup sebagai dasar pemutus perkara). Sesuai dengan bunyi Pasal 1870 KUHPerdata: "Bagi para pihak yang berkepentingan beserta para ahli warisnya ataupun bagi orang-orang yang mendapatkan hak dari mereka, suatu akta otentik memberikan suatu bukti yang sempurna tentang apa yang termuat di dalamnya" Dengan adanya celah bahwa akta otentik tersebut dapat didegradasikan menjadi akta di bawah tangan, sehingga pihak ketiga yang berkepentingan tersebut memiliki kemungkinan untuk memenangkan gugatannya. 
Apabila suatu saat terjadi sengketa yang mempermasalahkan tentang jual-beli tersebut, maka perjanjian jual beli di bawah tangan tersebut dapat dijadikan suatu alat bukti, meski kekuatan pembuktiannya adalah lemah.

Teori perlindungan hukum yang dikemukakan oleh Satjipto Rahardjo tersebut apabila dikaitkan dengan permasalahan yang terjadi di lapangan, maka hukum telah melindungi pembeli apabila suatu saat terjadi sengketa yang timbul atas jual beli tanah tersebut, karena meskipun dibuat secara dibawah tangan, maka perjanjian jual beli tersebut sudah memenuhi syarat-syarat perjanjian dan asas perjanjian yang diatur dalam hukum perdata, dimana suatu perjanjian tersebut akan mengikat dan menjadi undang-undang bagi para pihak yang telah membuatperjanjian tersebut (asas pacta sun servanda), sehingga perjanjian tersebut dapat menjadi sebuah alat bukti, meskipun mempunyai kekuatan pembuktian sebatas kuat, belum sempurna. ${ }^{15}$ Maka dengan demikian perlindungan hukum merupakan

${ }^{15}$ Satjipto Rahardjo,Op.Cit, hal.49 suatu perlindungan terhadap Hak Asasi Manusia terhadap perbuatan merugikan yang dilakukan oleh orang lain, maka dalam hal ini perjanjian dibawah tangan tadi sudah dapat dijadikan suatu perlindungan hukum tentang keabsahan dalam perbuatan hukum jual-beli hak atas tanah tersebut. Namun demikian apabila pembeli ingin melakukan balik nama menyangkut hak atas tanah tersebut, perjanjian dibawah tangan tersebut tidak dapat dijadikan sebagai acuan untuk didaftarkan ke Kantor Pertanahan.

\section{KESIMPULAN}

Berdasarkan pemaparan yang telah diberikan pada bab-bab sebelumnya maka dapat ditarik suatu simpulan sebagai berikut

1. Akibat hukum dari akta jual beli yang tidak sesuai dengan pembuatannya antara lain :

a. Akta akan terdegradasi menjadi akta dibawah tangan.

b. Tidak dapat mendaftarkan peralihan hak atas tanahnya (balik nama) sertifikat ke Kantor Pertanahan setempat. 
c. Tidak mendapatkan suatu alat pembuktian yang kuat apabila kelak tanah yang dibelinya terjadi sengketa.

d. Pembeli tidak dapat menjaminkan sertifikatnya untuk memperoleh kredit yang diajukannya, tanpa melibatkan pihak penjual tanah yang bersangkutan.

2. Perlindungan hukum bagi pembeli terhadap jual beli hak atas tanah yang dilakukan secara dibawah tangan adalah bukti perjanjian tersebut, meskipun dilakukan secara dibawah tangan, tetapi hal tersebut dapat dijadikan suatu bentuk perlindungan hukum karena dapat menjadi suatu alat bukti dengan kekuatan pembuktian yang lemah. Hal tersebut dapat ditemukan dalam Pasal 1866 KUHPerdata, dan dipertegas dalam Pasal 1874 KUHPerdata yang menyebutkan tentang suatu alat bukti dapat merupakan suatu tulisan yang dibuat secara dibawah tangan. Sehingga hukum telah melindungi pihak pembeli apabila suatu saat terjadi sengketa, namun apabila ingin melakukan balik nama maka para pihak baik penjual maupun pembeli harus membuat akta jual beli yang dibuat oleh PPAT sebagai landasan untuk melakukan balik nama di Kantor BPN.

\section{SARAN}

Berdasarkan hasil penelitian dan kesimpulan di atas, maka penulis menyarankan hal-hal sebagai berikut:

1. Untuk para pihak.

Bagi para pihak sebaiknya menanyakan kepada PPAT tentangprosedur pembuatan akta yang benar sehingga terhindar darikemungkinan terancamnya kepastian hak atas tanah yangdiperoleh.Para pihak harus dapat bekerjasama dengan PPATdalam melaksanakan pembuatan akta jual beli sehingga akta yangdihasilkan dapat 
menjamin kepastian hak atas tanah yangdiperjualbelikan.

2. Untuk Pemerintah.

Faktor-faktor

yang

mempengaruhi PPAT dalam pembuatan

aktajual beli tanah, baik faktor-faktor

hukum maupun faktor-faktor

nonhukumbegitu beragam, maka tata

cara pembuatan akta yangsemata-mata

hanya berlandaskan pada unsur

kepastian hukumsemata-mata

sebaiknya ditinjau atau

dipertimbangkan kembali. Halini

disebabkan akan banyak kepentingan

klien yang tidak bisadilayani kalau

semata-mata hanya memperhatikan

unsur kepastianhukum. Perlulah

kiranya dinamika-dinamika yang

berkembangdalam pembuatan akta

PPAT ditampung atau di akomodasi

dalamundang-undang atau peraturan-

peraturan sehingga dalampembuatan

akta PPAT unsur kepastian hukum

dapat terpenuhi dansebaliknya unsur

pelayanan terhadap masyarakat pengguna jasaPPAT juga dapat

terakomodasi dengan baik.

DAFTAR PUSTAKA

Achmad Rubaie, 2007, Hukum Pengadaan Tanah Untuk Kepentingan Umum, Bayumedia, Malang.

Ali Achmad Chomsah, 2004, Hukum Agraria (Pertanahan Indonesia) Jilid 2, Prestasi Pustaka Publisher. Jakarta.

Boedi Harsono, 2007, Hukum Agraria Indonesia Sejarah Pembentukan Undang-Undang Pokok Agraria, Isi dan Pelaksanaannya, Djambatan, Jakarta.

Herlien Budiono, 2006, Asas Keseimbangan Bagi Hukum Perjanjian Indonesia Hukum Perjanjian Berlandaskan Asas-Asas Wigati Indonesia, PT. Citra Aditya Bakti, Bandung.

Ida Nurlinda, 2009, Prinsip-Prinsip Pembaruan Agraria Perspektif Hukum, Rajawali Pers, Jakarta.

J. Kartini Soedjendro, 2001, Perjanjian Peralihan Hak Atas Tanah Yang Berpotensi Konflik, Kanisius, Yogyakarta.

JW.Muliawan, 2009, Pemberian Hak Milik Untuk Rumah Tinggal, Cerdas Pustaka Publisher, Jakarta.

P. van Warmelo, 1976, An Introduction to the Principles of Roman Law, Juta and Co Ltd, Cape Town. 